${ }^{9}$ Dallapiccola B, Bollea G, Mazzilli C, Gandini E. Complex translocation $\mathrm{t}(9 ; 21)(9 ; 22)(\mathrm{q} 12 \mathrm{p} 13)(\mathrm{q} 12 \mathrm{q} 11)$ in the family of a child with 9p trisomy syndrome. Hum Genet 1976;33:73-6.

${ }^{10}$ Muneer RS, Donaldson DL, Rennert OM. Complex balanced translocation of chromosomes 2, 3 and 13. Hum Genet 1981;59:182-4.

1 Hustinx TWJ, Nabben FAE, Scheres JMJC. Partial trisomy of chromosome 1 resulting from a complex maternal rearrangement of chromosome 1, 5 and 6. Am J Med Genet 1979;3:353-8.

12 Tanaka N, Ikeuchi T, Yara I, Kitahara K. Trisomy 9p due to a maternal complex translocation involving chromosomes 4,6 and 9. Jpn J Hum Genet 1977;21:261-8.

${ }^{13}$ Ballesta F, Fernandez E, Mila M. Translocation $t(1 ; 8 ; 15)$ maternelle et trisomie 8qter chez la fille. J Genet Hum 1980;28:361-6.

14 Tabor A, Jensen LK, Lundsteen C, Niebuhr E. A 5;7, 5;12 double reciprocal translocation in a normal mother and a $5 ; 7$ translocation with a recombinant chromosome 5 in her normal child. J Med Genet 1980;17:307-9.

${ }^{15}$ Fredga K, Hall B. A complex familial translocation involving chromosomes 5, 9 and 13. Cytogenetics 1970;9:294-306.
${ }^{16}$ Seabright M, Gregson N, Pacifico E, et al. Rearrangements involving four chromosomes in a child with congenital abnormalities. Cytogenet Cell Genet 1978;20:150-4.

17 Buchana PD, Rao KW, Doerr CL, Aylsworth AS. A complex translocation involving chromsomes 3,11 and 14 with an interstitial deletion, del(14)(q13q22) in a child with congenital glaucoma and cleft lip and palate. Birth Defects 1978;14(6C):317-22.

18 Watt JL, Couzin DA. De novo translocation heterozygote with three reciprocal translocations. J Med Genet 1983;20:385-8.

19 Couzin DA, Watt JL, Auchterlonie IA. A complex double translocation involving four chromosomes and five breakpoints in a child with mild mental retardation. J Med Genet 1983;20: 389-92.

Correspondence and requests for reprints to $\mathrm{Dr}$ M H Bogart, Cytogenetics Laboratory M-013, Division of Medical Genetics, Department of Medicine, University of California, San Diego, La Jolla, California 92093, USA.

\title{
Primary myelodysplastic syndrome with complex chromosomal rearrangements in a patient with Klinefelter's syndrome
}

\author{
S M NAOROSE ABIDI*, M GRIFFITHS $\dagger$, D G OSCIER*, G J MUFTI*, \\ AND T J HAMBLIN* \\ *Department of Haematology, Royal Victoria Hospital, Bournemouth BH1 4JG; and †Wessex Regional \\ Cytogenetics Unit, Salisbury General Hospital, Salisbury SP2 7SX.
}

SUMmARY A patient with Klinefelter's syndrome and diabetes mellitus was diagnosed as having myelodysplasia. Cytogenetic analysis of the peripheral blood and the bone marrow cells confirmed the presence of a constitutional $47, \mathrm{XXY}$ chromosome complement. In addition, complex karyotypic abnormalities were present.

Several studies have suggested an increased incidence of extragonadal germ cell tumours, ${ }^{1}$ carcinoma of the breast, ${ }^{2}$ and acute myeloid leukaemia ${ }^{3-5}$ in patients with Klinefelter's syndrome. In this report we describe a patient with Klinefelter's syndrome who developed a preleukaemic state (myelodysplastic syndrome). Cytogenetic analysis of the bone marrow and peripheral blood of this patient showed a constitutional $47, \mathrm{XXY}$ chromosome complement. In addition, complex karyotypic abnormalities were present. The significance of these findings is discussed.

Received for publication 21 August 1984

Accepted for publication 24 August 1984 .

\section{Case report}

A male Caucasian, aged 68, presented with a four month history of increasing breathlessness. Eight years previously he had been admitted to another hospital in a hyperosmolar, non-ketotic diabetic coma and at that time he was noted to be tall (185 $\mathrm{cm}$ ) and to have hypogonadism and prognathism. $\mathrm{He}$ had been investigated for acromegaly and was found to have raised levels of FSH and $\mathrm{LH}$ and normal levels of TSH, free T4, growth hormone, and prolactin. Skull $x$-ray showed a normal pituitary fossa. His diabetes had been controlled with oral hypoglycaemic agents and the only other drug therapy he had received was testosterone at six monthly intervals. He was unmarried and had no children. He had no history of exposure to chemicals.

On presentation at this hospital he was noted to be pale and lacking facial and body hair. $\mathrm{He}$ had gynaecomastia and small testes. Full blood count showed Hb $7.5 \mathrm{~g} / \mathrm{dl}$, WBC $3.5 \times 10^{9} / 1$ (neutrophils $46 \%$, lymphocytes $45 \%$, monocytes $3 \%$, eosinophils $6 \%$ ), and platelets $309 \times 10^{9} / 1$. Blood film showed dimorphic red cells, hypogranular neutrophils, and platelet anisocytosis. Bone marrow aspirate showed 
TABLE Karyotype of peripheral blood and bone marrow.

\begin{tabular}{lc}
\hline Karyotypes & No of cells \\
\hline Bone marrow & \\
45,XXY, $-5,-7,-12,-21,+\mathrm{m}^{1},+\mathrm{m}^{2}, \mathrm{del}(3 \mathrm{p})$ & 3 \\
$46, \mathrm{XXY},-5,-7,-12,-21,+\mathrm{m}^{1},+\mathrm{m}^{2},+\mathrm{fra}, \mathrm{del}(3 \mathrm{p})$ & 2 \\
46,XXY, $-5,-7,-21,+\mathrm{t}(7 \mathrm{p}: 21 \mathrm{q}),+\mathrm{m}^{1}, \mathrm{t}(3 ; 12)(\mathrm{p} 21 ; 13)$ & 2 \\
47, XXY & 4 \\
Total & 11 \\
Peripheral blood & \\
With PHA & 10 \\
47.XXY & \\
Without PHA & 1 \\
46.XXY, $-5,-7,-12,-21,+\mathrm{m}^{1},+\mathrm{m}^{2},+$ fra, del $(3 \mathrm{p})$ & \\
\hline
\end{tabular}

dyserythropoietic erythroid hyperplasia and dysplastic features in both granulopoiesis and thrombopoiesis. The myelogram showed $82 \%$ erythroblasts and $2 \%$ myeloblasts. Iron stain revealed that $68 \%$ of the erythroblasts were ring sideroblasts.

Cytogenetic analysis of bone marrow and peripheral blood cells showed a 47, XXY constitutional chromosome complement. In addition, cell lines with complex rearrangements were detected in $64 \%$ of cells from 24 hour cultures of bone marrow (table). All the abnormal cells showed monosomy 5. In one cell, rearrangements between $7 p$ and $21 q$ were identified (resulting in monosomy $7 q$ ) and in another cell a $\mathrm{t}(3 ; 12)(\mathrm{p} 21 ; \mathrm{p} 13)$ was present. A small unidentifiable marker was also seen.

A diagnosis was made of Klinefelter's syndrome and of refractory anaemia with ring sideroblasts. The patient is being treated by blood transfusion at six weekly intervals and maintains an otherwise stable condition.

\section{Discussion}

In 1961 the first case of acute myeloid leukaemia in a patient with Klinefelter's syndrome was reported. ${ }^{5}$ Since then at least 12 more such associations have been documented. Muts-Homsma et al ${ }^{4}$ performed cytogenetic analysis on 51 adult males with acute myeloid leukaemia and found five patients to have a chromosome complement of $47, \mathrm{XXY}$. On the basis of these figures it was estimated that Klinefelter's syndrome patients have a 100 -fold increased risk of developing acute myeloid leukaemia compared to the normal population.

The myelodysplastic syndrome constitutes a group of disorders in which the bone marrow is progressively replaced by an abnormal clone of haemopoietic cells. The patients usually present with anaemia associated with neutropenia or thrombocytopenia or both. The FAB Cooperative Group have identified five sub-groups of myelodysplastic syndrome. ${ }^{\circ}$ These comprise refractory anaemia, refractory anaemia with ring sideroblasts, refractory anaemia with excess of blasts, refractory anaemia with excess of blasts in transformation, and chronic myelomonocytic leukaemia.

It is estimated that 17 to $25 \%$ of all patients with myelodysplastic syndrome transform to acute myeloid leukaemia. ${ }^{78}$ Non-random chromosome anomalies, such as monosomy 5 , monosomy 7 , and trisomy 8 , are commonly found in patients with these conditions. These facts together suggest a close link between the two disorders. Patients with myelodysplastic syndrome who show complex karyotypic abnormalities at presentation have an especially high risk of developing acute leukaemia. ${ }^{8}$

In our previously reported series of 141 cases of myelodysplastic syndrome ${ }^{8} 26$ patients had refractory anaemia with ring sideroblasts and had normal chromosomes or single stable abnormalities at presentation. The Klinefelter's syndrome patient reported here was not included in this series. He is unusual in that, at the time of diagnosis of refractory anaemia with ring sideroblasts, cytogenetic analysis showed cell lines with complex chromosome rearrangements. Although this is considered to be the most benign form of myelodysplastic syndrome, with very few patients in this category developing acute myeloid leukaemia, our experience of patients with myelodysplastic syndrome who have complex karyotypic abnormalities suggest that this patient is at grave risk of developing acute leukaemia.

Mukerjee et al have shown that XXY cell lines manifest a three-fold increase in their susceptibility to SV 40 transformation compared to normal cells. However, the events at the genetic level which may predispose Klinefelter patients' cells to become malignant have yet to be elucidated.

\section{References}

1 Turner AR, McDonald RN, Gilbert JA, Petursson S. Mediastinal germ cell cancers in Klinefelter's syndrome (letter) Ann Intern Med 1981;94:279.

2 Jackson AW, Muldal S, Ockey CH, O'Connor PJ. Carcinoma of the male breast in association with the Klinefelter syndrome. Br Med J 1965;1429:223-5.

${ }^{3}$ Geraedts JP, Mol A, Briet E, Hartgrink-Groenveld CA, den Ottolander GJ. Klinefelter syndrome: predisposition to acute non-lymphocytic leukaemia? (letter). Lancet 1980;i:774.

${ }^{4}$ Muts-Homsma SJ, Muller HP, Geraedts JP. Klinefelter's syndrome and acute non-lymphocytic leukemia. Blut 1982;44:15-20.

5 Mamunes P, Lapidus PH, Abbott JA, Roath S. Acute leukaemia and Klinefelter's syndrome. Lancet 1961;ii:26-7.

${ }^{6}$ Bennett JM, Catovsky D, Daniel MT, et al (FAB Cooperative group). Proposals for the classification of the myelodysplastic syndromes. Br J Haematol 1982;51:189-99.

7 Rosenthal DS, Moloney WC. Refractory dysmyelopoietic anaemia and acute leukaemia. Blood 1984;63:314-8.

8 Mufti GJ, Stevens J, Oscier DG, Hamblin TJ, Machin D 
Myelodysplastic syndromes: a scoring system with prognostic significance. Br J Haematol 1985;59:425-33.

9 Mukerjee D, Bowen J, Anderson DE. Simian papovirus 40 transformation of cells from cancer patient with XY-XXY mosaic Klinefelter's syndrome. Cancer Res 1970;30:1769-72.
Correspondence and requests for reprints to Dr D G Oscier, Department of Haematology, Royal Victoria Hospital, Shelley Road, Bournemouth BH1 4JG.

\title{
Partial trisomy $6 \mathrm{p}$ and partial trisomy 22 resulting from 3:1 meiotic disjunction of maternal $(6 p ; 22 q)$ translocation
}

\author{
P R SCARBROUGH*, A J CARROLL*, S C FINLEY*†, AND K HAMERICK* \\ ${ }^{*}$ Laboratory of Medical Genetics and + Department of Pediatrics, University of Alabama at Birmingham, \\ Birmingham, Alabama, USA.
}

SUMmARY A male infant, partially trisomic for a small segment of chromosomes 6 and 22 resulting from a maternal translocation, is described. Comparison of the phenotypic features of the proband with those noted in partial $6 \mathrm{p}$ and partial 22 trisomies revealed some common features found in both chromosome anomalies but especially reinforced those features thought to be characteristic of $6 p$ trisomy syndrome.

\section{Case report}

A 13 day old white male (fig 1) was the $2780 \mathrm{~g}$ product of a 38 to 39 week gestation for a 22 year old gravida 2 (FO, PO, Abl, LO) mother. Admission to

Received for publication 3 January 1985.

Revised version accepted for publication 13 February 1985. hospital and hormone injections were required to maintain the pregnancy complicated by first trimester bleeding. Maternal drug or alcohol abuse, radiation or chemical exposure, and smoking were denied. Family history was remarkable for several maternal relatives with multiple miscarriages and several unexplained early infant deaths.

Caesarean section was performed because of maternal toxaemia. Polyhydramnios was noted at delivery. The neonatal course was complicated by hyperbilirubinaemia and hypoglycaemia.

Physical examination showed a vigorous infant with microcephaly, facial asymmetry, overriding sagittal suture, small anterior fontanelle, right sided microphthalmia, blepharophimosis, blepharoptosis, downward slanting palpebral fissures, mild hypertelorism, slightly flattened nasal bridge, flammeus naevus over the nasal bridge and nape of the neck, bilateral preauricular pits, holosystolic murmur, partial soft tissue syndactyly of the second to fourth
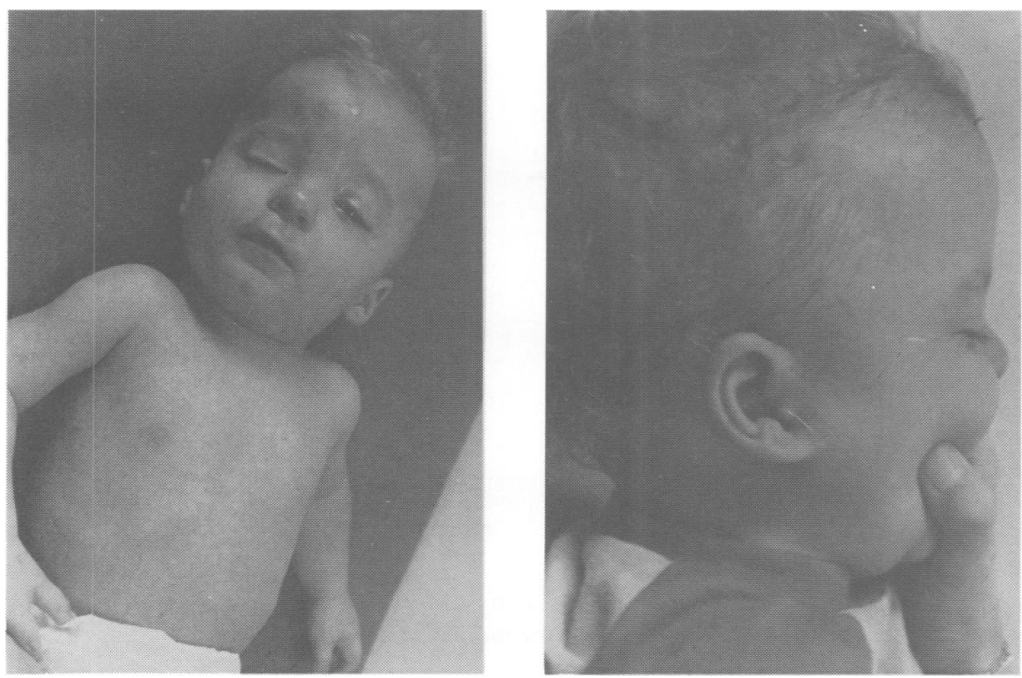

FIG 1 The proband at 15 months. 